Julia TARNAWSKAJA

Instytut Filozofii i Socjologii PAN, Warszawa

\title{
W co wierzą młodzi? Badania socjologiczne nad religijnością młodzieży studiującej w Warszawie
}

Taka jest religijność młodych Polaków, którzy - wstępując na studia wyższe - zamierzają ,zasilić” niebawem szeregi nowej klasy średniej? Jak łączy się ich wiara z innymi postawami życiowymi i przekonaniami, z polityką i moralnością? Czy ciągle przeważa tu, jak przed rokiem 1989, tradycyjny katolicyzm obrzędowy, przyjmowany bezrefleksyjnie i automatycznie od starszych pokoleń? Czy katolicyzm ów utożsamiany jest nadal z polskością i traktowany jako „wiara polityczna”? Czy też może, pod ciśnieniem nowych wolności ekonomicznych, politycznych, społecznych i kultury masowej, dokonały się jakieś gwałtowne zmiany?

Starałam się odpowiedzieć na te i inne jeszcze pytania w badaniach, które przeprowadziłam w styczniu 2001 roku wśród studentów dwóch renomowanych uczelni - Uniwersytetu Warszawskiego oraz, działającej także w Warszawie, Wyższej Szkoły Informatyki Stosowanej i Zarządzania (pod auspicjami PAN). A wyniki moich badań ukazują, iż w mentalności tej wielkomiejskiej i studiującej młodzieży nastąpił już szereg rozmaitych przeobrażeń, niekiedy bardzo interesujących, ale trudno mówić tutaj o jakimś radykalizmie zmian, o jakiejś „rewolucji” religijnej czy moralnej. I znamienne jest raczej dążenie do kompromisu - do godzenia tradycji, ciagle żywej i ważnej, z nowymi doświadczeniami, jakie niesie liberalna demokracja, kultura masowa czy duchowość New Age.

\section{Ogólna charakterystyka badanej grupy młodzieży}

$\mathrm{Na}$ ankietę moją odpowiadali studenci I roku trzech kierunków (kulturoznawstwa, informatyki i filologii polskiej) - w sumie 196 osób (67\% stanowili chłopcy, 33\% dziewczęta). Najmłodszy z badanych liczył wprawdzie ledwie 17 wiosen, a najstarszy 27, jednak przeważali tu ludzie w wie- 
ku 19-21 lat (sporo było również osób mających 22-23 lata). Jest to istotne o tyle, że ci młodzi ludzie znajdują się w okresie przejściowym między szkołą średnią a studiami - toteż ich poglądy mogą być charakterystyczne dla obu środowisk. W swej większości studenci pochodzą z Warszawy i jej okolic (w przypadku informatyków także z całego Mazowsza i Podlasia). Tworzą oni grupę w miarę jednorodną pod względem społecznym - ojcowie zdecydowanej większości studentów mają wykształcenie wyższe lub średnie. Zarazem jednak jest to grono młodych ludzi o rozmaitych - często różniących się w dość dużym stopniu - przekonaniach i wyobrażeniach.

Jeśli chodzi o przekonania polityczne, najbardziej popularne wśród studentów są poglądy liberalno-demokratyczne, z którymi sympatyzuje ponad połowa badanych (53\%). Prawdopodobnie ten liberalno-demokratyczny wybór jest jednak deklaratywny i dokonuje się pod presją panującego idiomu publicznego. Druga co do wielkości grupa (12\%) to młodzież nastawiona apolitycznie. Najmniej popularne są poglądy konserwatywne (4\%) i komunistyczne (3\%). Jednakże zarazem jedna trzecia ankietowanych podziela niektóre idee komunizmu. Mniej więcej tyle (27\%) częściowo podziela postulaty polskich organizacji narodowych, choć ledwie $9 \%$ wyraża jawną sympatię dla takich politycznych poglądów. A co dziesiąty student jest zwolennikiem idei socjalistycznych (i tylko nieco mniej, bo 7\%, przychyla się do anarchizmu). Większość charakteryzuje przychylny lub obojętny stosunek do komunizmu i neutralne podejście do tzw. idei narodowych. Wskazywać to może, że ani radykalny antykomunizm, ani też nacjonalizm nie zdołają się szerzej zakorzenić.

Przedstawiona tu charakterystyka w pełni wiarygodnie wyraża nastawienia mentalne nie tylko badanych studentów, ale szerszych grup uczącej się młodzieży. Jednak należy zauważyć, że uczestniczący w moich badaniach nie są grupą dobraną reprezentatywnie. Znaczy to, że rezultaty owych badań nie moga zostać wykorzystane do opisu i analizy wszystkich studentów Warszawy, a tym bardziej Polski. Zgodnie z tym moje wywody o religijności, wierze i ogólnym światopoglądzie studentów nie będą wychodziły poza obszar przekonań ankietowanej grupy młodzieży.

Ważne także jest to, że w badaniach liczba chłopaków dwukrotnie przewyższyła liczbę dziewczyn. Z wszystkich dotychczasowych badań religijności w Polsce wynika, że kobiety są bardziej konsekwentnymi i fundamentalnymi ludźmi wiary niż mężczyźni i gorliwiej też ją prakty- 
kują. Moje badania także to potwierdziły: dziewczyny są bardziej religijne i bardziej tradycyjne w swojej wierze. Zatem aż 43\% z nich nie waha się co do istnienia Boga, a tylko 3\% w Boga nie wierzy. Tymczasem tylko $28 \%$ chłopaków wierzy w Boga, a aż $11 \%$ odrzuca jego istnienie. Ponadto też $60 \%$ dziewcząt jest katoliczkami, co stanowi o $22 \%$ więcej niż katolików-chłopców (38\%). Oprócz tego dziewczęta częściej czytają Pismo Św., dwa razy regularniej modlą się, częściej też uczęszczają do kościoła.

\section{Katolicyzm w spadku?}

Przytłaczająca większość studentów (91\%) - z wahaniami lub bez wierzy albo w Boga, albo w jakąś wyższą nieokreśloną siłę, a tylko 9\% nie wierzy $\mathrm{w}$ nic.
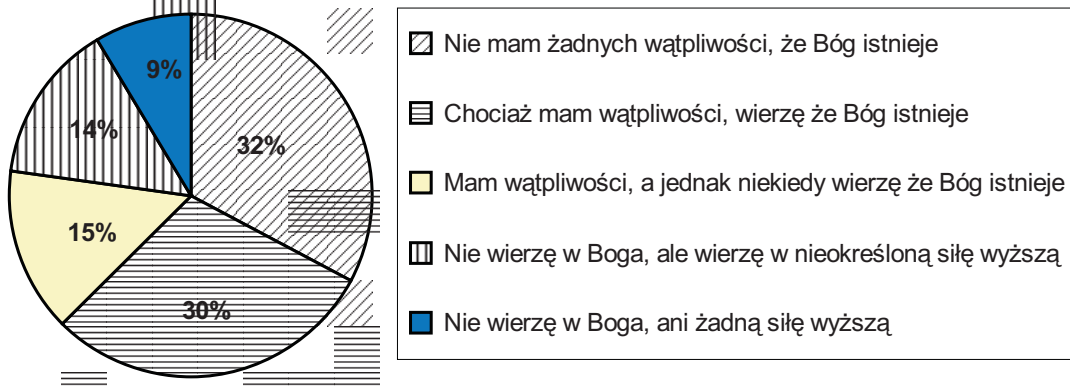

Zarazem też większość badanych (70\%) twierdzi, że zawsze wierzyła w Boga i wierzy weń teraz. Wprawdzie u mniej więcej jednej trzeciej w ciagu ostatnich 10 lat pojawiły się różne wątpliwości co do istnienia Boga, ale ich wiara pozostała niezmienna. Jednakże 13\% ją utraciło (większą część stanowią tu chłopcy z informatyki, których rodzice także nie wierzą). Ale jest także pośród studentów niewielka grupa (6\%) tych, którzy nigdy nie wierzyli w Boga, przy czym większość z nich pochodzi z katolickich rodzin.

Więcej niż połowa wierzących w Boga (53\%) podkreśliła jako zasadniczą przyczynę zwrócenia się ku Bogu tradycję rodzinną. Niemal dwukrotnie mniejsza liczba studentów (23\%) zwróciła się natomiast ku Bogu w poszukiwaniu sensu życia, a jeszcze mniej - pod wpływem nieokreślonego wewnętrznego impulsu (14\%). Rodzinna tradycja wywarła przy tym 
wpływ nie tylko na tych, którzy w ślad za rodzicami stali się członkami określonego wyznania, ale i na tych, którzy nie wyznają żadnej konkretnej religii (rodzice wychowali ich wprawdzie w wierze i swoim przykładem umocnili przekonanie o istnieniu Boga, chociaż dziecko nie powtórzyło ich wyznaniowej przynależności).

Należy także zwrócić uwagę na małą grupę kobiet i mężczyzn (3\% badanych), którzy zaznaczyli w ankiecie odpowiedź ,wcześniej nie wierzyłem w Boga, lecz teraz wierzę". Przyczyną zwrócenia się ku wierze były w tym przypadku własne poszukiwania sensu życia lub nieokreślony impuls wewnętrzny. Ponadto rodzice połowy respondentów z tej grupy są katolikami, zaś drugiej połowy - ateistami, co pozwala wnioskować, iż nie zawsze tradycja rodzinna przesądza o wyborze religijnym dzieci.

Jednakże to właśnie wychowanie rodzinne najczęściej decyduje o wyborze wyznania. Jak bowiem wykazała moja analiza, około $60 \%$ młodych ludzi naśladuje religię swoich rodziców. Tendencja taka jest szczególnie zauważalna w przypadku rodzin katolickich - 84\% młodych ludzi wyznających katolicyzm stwierdza, że przyczyną wyboru ich wyznania była tradycja rodzinna, a tylko 5\% kierowało się przy wyborze własnymi poszukiwaniami prawdziwej wiary. Zatem można powiedzieć, że dla większości problem wyboru religii nie istniał. Religijne wychowanie przesądziło o punkcie wyjścia.

Zasługuje na uwagę to, że matki są bardziej religijne niż ojcowie (tylko $6 \%$ matek nie uznaje siebie za wierzące wobec $15 \%$ ojców). I oczywiście to one bardziej zajmują się religijnym wychowaniem dzieci i prowadzą rozmowy na temat wiary. Poświadcza to przypuszczenie fakt, że wiary ojca respondenci są świadomi dwukrotnie gorzej niż wiary matki. Tak więc tylko $12 \%$ nie może nic powiedzieć o tym, czy ich matka jest wierząca, czy nie, a zarazem $24 \%$ respondentów nie wie, czy ich ojciec wierzy w Boga.

Ponad połowa badanych zaliczyła siebie do wyznania katolickiego (59\%). 10\% oznajmiło zaś o swojej przynależności do «chrześcijaństwa». Niestety, trudno z pewnością orzec, jakie znaczenie młodzi ludzie wkładali $\mathrm{w}$ to pojęcie. Z pewnością niektórzy mylnie posługiwali się tym słowem, rozumiejąc pod mianem «chrześcijaństwa» wiarę katolicką. Inni - przeciwnie: pragnąc odciąć się od katolicyzmu, lecz wyznając wspólne wartości chrześcijańskie i wierząc w Jezusa, najzupełniej właściwie umieścili się wśród chrześcijan. Oprócz katolików i owych «chrześcijan» wśród respondentów ujawnili się pojedynczy przedstawiciele prawosławia, luteranizmu, staroobrzędowców, grekokatolicyzmu i Świadków Jehowy 
(w sumie 2\%). 13\% studentów uważa się za wierzących, lecz nie przynależących do żadnego wyznania, a 16\% ma siebie za niewierzących.

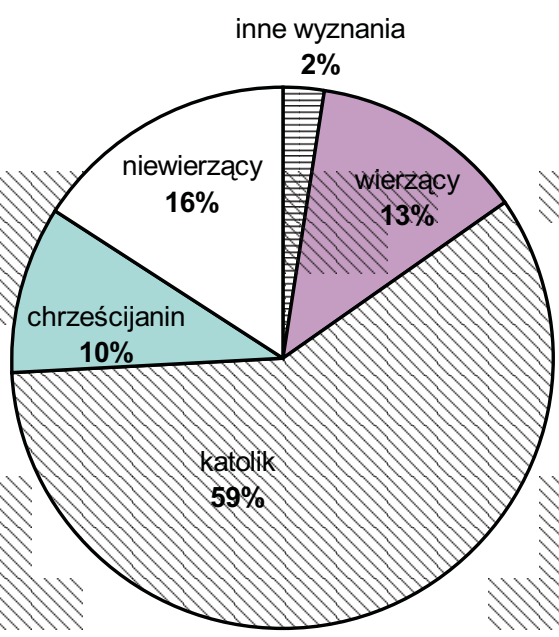

Nie wszyscy ci, którzy deklarują swoją przynależność do religii katolickiej, są wierzącymi - jedna piąta z nich nie uważa siebie za wierzących. Świadczy to o rzeczywiście silnym wpływie katolickiej tradycji, w którego rezultacie samorozpoznanie się człowieka jako katolika zachodzi niezależnie od tego, czy wierzy on w Boga, czy też nie.

Mocne oddziaływanie polskiej tradycji religijnej wyraża się także poprzez to, że dla $85 \%$ badanych ma ona «dość duże znaczenie». Przede wszystkim zaś oczywiście to katolicyzm jest przez wielu studentów przyjmowany jako nieodłączna część nie tylko tradycji rodzinnej, lecz także polskiej historii i kultury. Jednocześnie jednak wśród młodych ludzi zaznaczyło się odejście od utożsamiania wartości narodowych i religijnych.

Zaledwie bowiem 13\% ankietowanych uznało, że aby być Polakiem, ważne jest również wyznawanie katolicyzmu. Dla porównania, za ważnością lojalnego odnoszenia się do państwa opowiedziało się w tym samym pytaniu $87 \%$, przestrzegania polskiego prawa $-82 \%$, przestrzegania zasad demokracji - 79\%, zaś duże znaczenie narodowości polskiej podkreśliło 76\%. Wzrostowi znaczenia obowiązków obywatelskich towarzyszy tu więc gwałtowne zmniejszenie się roli czynnika wyznaniowego. Czy zatem - stwierdzając duży wpływ polskiej tradycji religijnej - możemy jednocześnie mówić o oznakach odrzucenia poszczególnych jej składników przez współczesną młodzież (bo, poczynając od Stefana Czarnowskiego 
Czy twoim zdaniem, aby być Polakiem ważne jest:

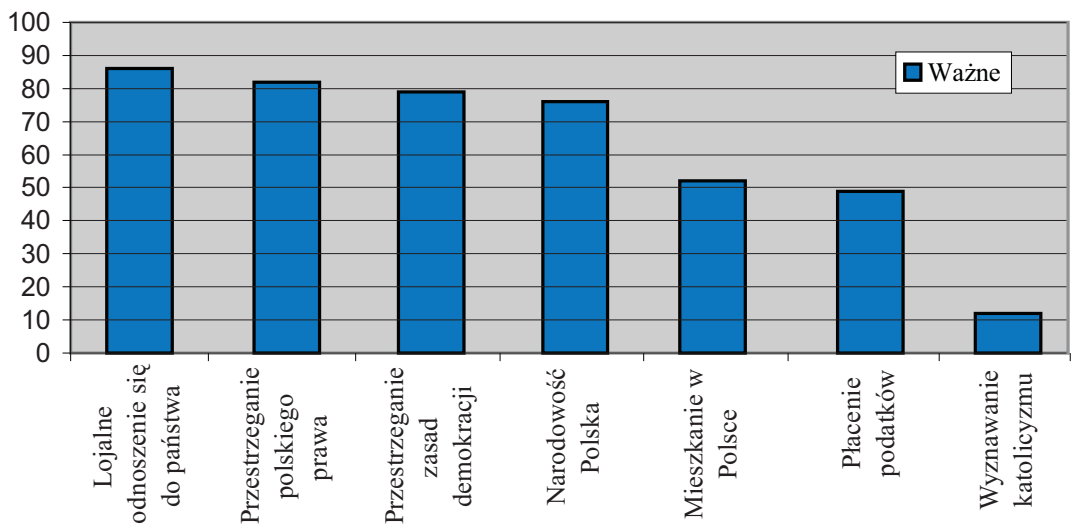

i jego koncepcji «nacjonalizmu wyznaniowego», właśnie tożsamość polskości i katolicyzmu przez wielu socjologów uważana była za jedną z głównych cech polskiej tradycji religijnej)? W świetle wyników mojego badania muszę nie tylko udzielić pozytywnej odpowiedzi na to pytanie, lecz także podkreślić, iż negacja niektórych utartych w przeszłości wzorów uczestnictwa w życiu religijnym ujawnia się wśród młodych ludzi na kilka co najmniej sposobów.

\section{Zbędność obrzędów}

Dla zrozumienia religijności badanych ważne znaczenie ma to, że z jednej strony $91 \%$ z nich oświadcza, że wierzy w Boga lub jakąś siłę wyższa, a z drugiej strony tylko $70 \%$ pytanych uznaje siebie za wierzących. Innymi słowy, 21\% - nie bacząc na to, że wierzy w Boga lub nieokreśloną siłę wyższą - nie uważa siebie za ludzi wierzących. W skład tej grupy wchodzą po części ci, którzy wierzą w Boga, ale mają wątpliwości, oraz część tych, którzy dopuszczają istnienie jakiejś wyższej siły. Z pewnością w świadomości tej pojęcie człowieka wiary jest związane z tradycyjnym obrazem praktykującego chrześcijanina. W ten sposób dla owej grupy warunkami niezbędnymi do tego, aby uważać się za wierzącego, okazuje się pozbawiona wątpliwości wiara w Boga (a nie w jakąś wyższą siłę) i uczestnictwo w praktykach religijnych. Potwierdza to także fakt, iż największa grupa studentów (37\%) twierdzi, że prawdziwie wierzący to ten, kto wierzy w Boga (dla 12\% oznacza to wyłącznie wiarę w Chrystu- 
sa), zna główne prawdy swojego Kościoła, wypełnia nakazy religijne oraz bierze udział w obrzędach.

Nie wszyscy jednak studenci podzielają taki punkt widzenia. Co trzeci $\mathrm{z}$ nich uznał bowiem, że prawdziwie wierzącym człowiekiem jest ten, «kto wierzy w istnienie jakiejś wyższej siły, która w istotnym stopniu określa jego życiowe cele, normy moralne i wpływa na jego działania». Znaczy to, że dla nich wiara właśnie w Boga i uczestnictwo w obrzędach nie okazuje się czymś zasadniczym. Nadto $24 \%$ nie przypisuje także znaczenia do spełniania religijnych praktyk, chociaż wiarę w Boga uważa za niezbędny warunek.

$42 \%$ badanych uważa, że religijne obrzędy zostały ustanowione przez Boga i stanowią obowiązkowy przejaw wiary, jednakże aż połowa z nich (22\%) sądzi, że regularne uczestnictwo w praktykach religijnych nie jest obowiązkowe. Jeszcze większa cześć młodych ludzi (46\%) przekonana jest o tym, że obrzędy zostały wymyślone przez ludzi i dlatego w ogóle można ich nie przestrzegać. W ten sposób w swoich sądach o uczestnictwie $\mathrm{w}$ religijnych praktykach studenci mocno odeszli od tradycyjnego, obrzędowego stosunku do religii.

\section{W stronę religijności niewidzialnej}

Młodzi ludzie nie nadają większego znaczenia obrzędom kościelnym także wtedy, gdy chodzi o praktyczny wymiar życia codziennego. Tylko co czwarty z nich zatem, stosując się do zaleceń religijnych, uczęszcza do kościoła raz w tygodniu lub częściej. 17\% odwiedza świątynię raz lub kilka w miesiącu, zaś prawie połowa (46\%) - kilka razy do roku - z okazji wielkich świąt lub biorąc udział w nabożeństwach okolicznościowych. Dość liczna grupa (13\%) nie była w kościele ani razu w ciągu ostatnich 12 miesięcy, natomiast co trzeci ze studentów nigdy nie przystępuje do komunii.

Nie ulega wątpliwości, że wierzący młodzi katolicy, szczególnie zaś kobiety, bardziej rygorystycznie podchodzą do nakazów religijnych. Nie zmienia to jednak faktu, iż także spośród nich na mszę niedzielną regularnie uczęszcza 67\% kobiet i zaledwie 31\% mężczyzn. A więc kolejne oznaki odejścia od tradycyjnych relacji pomiędzy wiernymi a Kościołem można także zauważyć wśród wierzących katolików. Według moich obliczeń tylko $18 \%$ z nich uważa, że ,uczęszczanie do świątyni jest konieczne, aby obcować z Bogiem", niewielka zaś liczba osób (4\%) twierdzi 
wręcz, iż jest to ,absolutnie niepotrzebne”. Natomiast grupa najliczniejsza chodzeniu do Kościoła nie nadaje większego znaczenia lub nie ma na ten temat określonej opinii.

Kolejny sposób obcowania z Bogiem to modlitwa indywidualna. Bez względu jednak na to, że zdecydowana większość pytanych (79\%) zna teksty katolickich modlitw, studenci się modlą jeszcze rzadziej, niż uczęszczają do kościoła. Co czwarty z nich nie modli się wręcz nigdy, zaś 30\% robi to bardzo rzadko. $24 \%$ studentów modli się kilka razy na miesiąc lub kilka razy na tydzień oraz $21 \%$ - codziennie. To więc, że nawet większość (58\%) nie uważających się za katolików i nie wierzących w Boga zna modlitwy katolickie, świadczy - po raz kolejny - wyłącznie o silnym oddziaływaniu polskiej tradycji religijnej, w której ramach dokonała się transmisja wiedzy religijnej.

Mniej jeszcze potrzebna wydaje się pytanym lektura Pisma Św., którego $31 \%$ nigdy nie czytało, a co czwarty od dawna nie miał w ręku. 39\% rzadko korzysta z Pisma, zaś zaledwie 6\% czyta go regularnie.

Można zatem powiedzieć, że wśród badanych dosyć wyraźnie się zarysowuje zniechęcenie do - niejednokrotnie nawet podstawowych - praktyk religijnych. Ten proces ponadto możemy obserwować nie tylko w przypadku tych, którzy wahają się, gdy chodzi o uznanie się za osobę wierzącą lub nie należących do jakiegoś wyznania, lecz także wśród katolików pewnych istnienia Boga. Tendencję taką nie można uznać za masowa, lecz jednocześnie nie ulega wątpliwości, iż obrzędy tracą na ważności i jednocześnie są przez młodzież rozpatrywane raczej jako część kulturowej tradycji kraju niżeli jako niezbędna oznaka wiary. Mamy tu zatem do czynienia z postulowanym przez socjologa Thomasa Luckmanna zjawiskiem «niewidzialnej religii». Polega ono właśnie na odejściu od religii w jej tradycyjnym rozumieniu. Kościół jako instytucja społeczna traci - podobnie jak obrzędy oraz wartości i normy tworzone przez środowisko kościelne - istotną rolę w życiu człowieka współczesnego. Wiara zaś przy tym, chociaż nie zanika, zmienia swój charakter, przesuwając się ze sfery publicznej do sfery indywidualnej.

\section{Bóg, diabel i UFO}

Takiemu dosyć pasywnemu podejściu do obrzędów religijnych towarzyszy kształtowanie się religijności synkretycznej, która łączy nie tylko chrześcijańską postawę ze światopoglądem świeckim, lecz zawiera także 
niektóre elementy okultystyczne i magiczne. Wystarczy bowiem powiedzieć, iż stosunkowo duża część badanych wierzy w - będącą odbiciem oddziaływania religii orientalnych i duchowości New Age - wędrówkę dusz (39\%), tyle samo w dobre i złe znaki (tu z kolei dość często są widoczne wpływy ludowych wyobrażeń magicznych oraz licznych zabobonów), UFO (35\%), telepatię (41\%) i telekinezę (31\%). Nie znaczy to, oczywiście, że wszyscy bez wyjątku studenci wierzą magom i wróżkom oraz korzystają z ich usług. Wizytę u wróżki ma za sobą 7\% badanych, zaś tylko 3\% kiedykolwiek zwracało się do medium lub astrologa. W świadomości religijnej badanych nauki chrześcijańskie przeważają jednak nad wiarą $\mathrm{w}$ magię lub astrologię.

Zaznaczyć jednak należy, że wiara w prawdy chrześcijaństwa ma raczej sceptyczno-selektywny niżeli polegający na bezkrytycznym ich przyjęciu charakter. Sceptyczny stosunek do niektórych aspektów nauki Kościoła stanowi także cechę studentów zaliczających się do wierzących katolików. Wystarczy powiedzieć, że 45\% z nich ma duże wątpliwości dotyczące możliwości nadejścia Antychrysta. Ponadto 14\% nie wierzy, że nastapi koniec świata oraz $28 \%$ - w powszechne zmartwychwstanie. Dla porównania: $22 \%$ wierzy w przepowiednie astrologów, $14 \%$ we wróżby, zaś 9\% - w skuteczność rzucenia złych uroków.

\section{Tolerancja i kara śmierci}

Chciałabym w końcu zwrócić uwagę na ogólną tolerancyjność badanych. Chociaż - jak zostało to powiedziane - młodzi ludzie mają częstokroć odmienne, między innymi tylko dotyczące kwestii wiary, poglądy, otwartość na różnego rodzaju nowe zjawiska i postawy ujawnia się wśród większości studentów. Szczególnie warte uwagi są tutaj, moim zdaniem, dwa główne wątki: wyrozumiałe podejście do różnorodnych religii oraz sceptyczne ustosunkowanie się młodzieży do niektórych zakazów kościelnych.

Stosunek studentów do głównych religii światowych, ogólnie rzecz biorąc, można określić jako pozytywnie-neutralny. Największą przychylność oczywiście zyskał katolicyzm (65\% badanych ma do niego pozytywny stosunek i $17 \%$ - neutralny). W przypadku buddyzmu stosunek procentowy wyniósł z kolei 47 i 39, prawosławia 42 i 40, zaś protestantyzmu 39 i 40 . Nieco mniejsza sympatia istnieje w stosunku do judaizmu (32\% i $43 \%$ ) oraz islamu ( $24 \%$ i $42 \%$ ). Na mniej pozytywnym stosunku do isla- 
mu zaważyło przy tym obiegowe jego utożsamianie, obecne często w mediach, $\mathrm{z}$ fundamentalizmem i terroryzmem arabskim, zaś w przypadku judaizmu u części studentów pokutują jeszcze - jak przypuszczam - stare stereotypy antyżydowskie. Takie, w sumie pozytywne, jak można sądzić, podejście do religii wykształciło się wśród młodych ludzi nie za sprawą ignorancji, lecz raczej jest przejawem świadomego wyboru. Większość badanych ma bowiem przynajmniej podstawową wiedzę co do głównych różnic pomiędzy wymienionymi wyznaniami, zaś tylko $4 \%$ nie zna nauk i zasad różniących religie.

O braku nastrojów fundamentalistycznych wśród badanych wymownie świadczy także przekonanie połowy z nich - w przypadku zaś wierzących katolików nawet większości - o tym, że wszystkie religie odwołują się do jednego Boga (27\% ogółu badanych nie zgadza się z tym twierdzeniem, 23\% nie ma zdania na ten temat). Dodajmy również, że w omawianym już po części punkcie ankiety, w którym studenci mieli do wyboru kilka definicji prawdziwie wierzącego człowieka, najmniej liczebna grupa badanych (11\%) wybrała najbardziej tradycyjne i zakładające wyłączność prawd chrześcijańskich określenie.

Z ogólną tolerancją młodzieży nie jest sprzeczny także ich stosunek do nowych ruchów religijnych. Chociaż zdecydowana większość pytanych (72\%) uważa, że działalność niektórych sekt i kultów powinna być zakazana, wynika to raczej z pragmatycznych - na pierwszym miejscu stawiających względy bezpieczeństwa neofitów - pobudek, niż za sprawą rozmyślań na temat prawdziwości wiary. Zatem już zakaz działalności wszystkich sekt i kultów jest pożądany zdaniem 7\% studentów. Badania moje tym samym dowodzą, że dla młodych ludzi nimi objętych satanizm nie jest paradygmatem sekty (że do sekt trafiają częściej niż inni sataniści sądzi mniej niż 3\%).

Mówiąc o otwartości i braku krytycyzmu wobec rozmaitych religii (z wyjątkiem islamu), muszę zwrócić jednocześnie uwagę, że o wiele liczniejsza, niż w przypadku innych religii, grupa studentów (17\%) ma negatywny stosunek do Kościoła katolickiego jako instytucji publicznej. Powodem takiego stanowiska dość wielu młodych ludzi wobec Kościoła jest $\mathrm{m}$.in. to, że ponad $40 \%$ nie ma do niego zaufania. Na pierwszy plan wysuwa się tu dokonywana przez 70\% studentów krytyka zbyt aktywnego mieszania się Kościoła do życia społeczno-politycznego oraz tego, że Kościół i organizacje katolickie mają za dużo władzy.

Negatywny stosunek wobec dążeń niektórych środowisk kościelnych do rozpowszechnienia swych wpływów na sferę życia świeckiego jest 
także jedną z przyczyn odrzucenia wielu zakazów religijnych. Ponad połowa bowiem studentów, nie zgadzając się tym samym z naukami katolicyzmu, uważa za dopuszczalne w życiu społecznym m.in. przedmałżeńskie stosunki seksualne (89\%), rozwód (78\%), aborcję $(55 \%)$, homoseksualizm (52\%) oraz karę śmierci (58\%). W tym ostatnim przypadku szczególnie wyraziście zaznacza się więc dychotomia pomiędzy religijną a świecką przestrzenią w świadomości badanych. Wyraźnie tolerancyjnemu odnoszeniu się do spraw związanych z wiarą niejednokrotnie towarzyszy bowiem graniczący wręcz z represywizmem wymagający stosunek w sferze obywatelskich obowiązków.

Wymienione zjawiska cieszą się dość dużym przyzwoleniem także wśród tych, którzy uważają się za katolików i wierzących. 37\% pośród nich dopuszcza więc aborcję, 70\% - rozwód, a 89\% - przedmałżeńskie stosunki seksualne. A więc także w tym przypadku - co wskazuje na stosunkową powszechność zjawiska w badanej grupie - mamy do czynienia z przesunięciem się punktu ciężkości, zdominowaniem podejścia religijnego przez poglądy laickie.

Toteż niewątpliwie pożądane jest ustalenie kolejnych - obok krytyki świeckich inicjatyw Kościoła - przyczyn takiego stosunku. Wymaga to kolejnych badań zarówno religijności, jak i całości postaw światopoglądowych polskiej młodzieży. Wyniki przeprowadzonej przeze mnie ankiety wskazują tylko na niektóre - zasadnicze, w moim przekonaniu przekształcenia na tym polu. W obrębie tej nawet analizy stwierdzić jednakże można, iż głównych przyczyn przemiany w podejściu do Kościoła należy doszukiwać się w sferze obejmującej wszystkie - po części tylko przeze mnie zarysowane - wyobrażenia religijne młodych Polaków. Znaczenie zaś zasadnicze będą tu miały, zachodzące w tle tradycyjnej wiary, zmiany samej religijności młodzieży.

\section{Summary}

The paper attempts to address a number of queries on religiousness of the Polish students, who are likely to constitute the new middle class soon. The author tries to present how their faith is related to other attitudes, beliefs, politics and morality. Is it still predominated by a traditional Catholic ritual, automatically inherited after older generations without any reflection, as it was before 1989? Is this Catholic faith still identified with being Polish and approached as a „political faith”? Or maybe some turbulent changes have taken place, enforced by new economic, political and social freedom or mass culture? 
The findings and conclusions presented in the paper are based on a survey conducted by the author in January 2001 among the students of the Warsaw University and the Warsaw School of Information Technology. They prove that mentality of the youth, who live in a large city and study, has already undergone a series of various transformations, some highly interesting, yet it is rather difficult to identify some radical changes or a religious and moral ,revolution". A common attempt at a compromise is also symptomatic here, the desire to harmonize the tradition, which is still lively and significant, with new experience provided by liberal democracy, mass culture or the spiritualism of New Age. 